\title{
ROLE OF SELENIUM AND VITAMIN E IN OCCUPATIONAL EXPOSURE TO HEAVY METALS (MERCURY, LEAD AND CADMIUM) : IMPACT OF WORKING IN LAMP FACTORY
}

\author{
$B \mathcal{Y}$ \\ Eman, Draz*; Rabab, El-Kelany*; Tarek, El- Nimr **; \\ Adel, Badawy*** and Soha, Zakaria**** \\ Departments of Forensic Medicine and Clinical Toxicology*, Neuropsychiatry ***, Biochemistry**** \\ Faculty of Medicine, Physics Department, Faculty of Science **Tanta University
}

\begin{abstract}
Heavy metals are environmental contaminants that may pose long-term health risks. Unfortunately, the consequent implementation of preventive measures was generally delayed, causing important negative effects to the exposed populations. The objective of this study was to determine whether coconsumption of nutritional supplements as selenium and vitamin E would treat the hazardous effects of exposure to mercury, lead and cadmium. Thirty-six workers (20 males and 16 females) were the subjects of this study, their ages ranged from 19-63 years, $(M=29.5 \pm 10.12)$. They were working in lamp factory for an average of 0.5-40 years $(M=5.3 \pm 8.8)$. Twenty control subjects matched for age and gender were used for comparison. All workers were subjected to neuropsychiatric evaluation. General Health Questionnaire (GHQ-28) revealed that $44.4 \%$ were complaining of anxiety, $52.7 \%$ of depression, $41.6 \%$ of social dysfunction and $22.2 \%$ of somatic symptoms. Cognitive tests revealed that long-term memory was not affected significantly when compared with controls, while short term memory and perceptual ability were affected significantly. Blood metal levels were measured by energy dispersive X-ray fluorescence $(E D X R F)$, and revealed that the mean blood mercury, lead and cadmium concentrations before treatment were $1.6 \mathrm{mg} / \mathrm{l}, 0.39 \mathrm{mg} / \mathrm{l}$ and $1.7 \mu \mathrm{g} / \mathrm{l}$, while they decreased significantly after treatment to $1.2 \mathrm{mg} / \mathrm{l}, 0.29$ $m g / l$ and $1.3 \mu \mathrm{g} / \mathrm{l}$ respectively. Anti-oxidative enzymes (paraoxonase and catalase) and lipid peroxidation product (malondialdehyde) were measured before and after treatment with selenium and vitamin $E$, and showed significant improvement. It could be concluded that co-consumption of selenium and vitamin E produces significant decrease in mercury, lead and cadmium levels in blood, and significant improvement in the antioxidative activity which may treat the neuropsychiatric disorders occasioned by chronic occupational exposure to heavy metals.
\end{abstract}

Keywords: mercury, lead, cadmium, neuropsychiatric impairment, selenium, vit E. 


\section{INTRODUCTION}

The sulfhydryl-reactive metals (mercury, cadmium, lead, and also arsenic) are particularly insidious and can affect a vast array of biochemical and nutritional processes. The symptoms associated with the slow accumulation of toxic metals are multiple and rather non descriptive, and overt expression of toxic effects may not appear until later in life (Quig, 1998).

Mercury (Hg) is used in many industrial implications as several types of electric lamps, including fluorescent lamps and high intensity discharge (HID) lamps; in electric light switches and thermostats, in dental amalgams and many other industries. Chronic exposure to elemental mercury yields a classic triad of gingivitis and salivation, tremor and neuropsychiatric changes (Goldwater, 1972), known as erethism including, irritability, emotional liability, memory loss, combativeness, anxiety, withdrawal and depression (Smith, 1978). The harmful effects of longterm exposure to elemental mercury are generally thought to be caused by inhalation exposure. However, mercury liquid and vapor are absorbed through the skin in small amounts and this route of exposure can contribute to the overall exposure. Effects following absorption through the skin are expected to be similar to those reported for long-term inhalation exposure. Long term mercury exposure causes harmful effects on the nervous, digestive and respiratory systems, and the kidneys (Agency for Toxic Substances and Disease Registry, 1990).

During the past century, lead (Pb) exposures in the workplace are common because of the widespread use of lead compounds in paints, gasoline, and industry. Human lead exposure occurs when dust and fumes are inhaled and when lead is ingested via lead-contaminated hands, food, water, cigarettes, and clothing. Lead entering the respiratory and digestive systems is released to the blood and distributed throughout the body. The most important aspects of lead toxicity are its effects on the central nervous system, which may be irreversible; however, lead affects all organs and functions of the body to varying degrees (Agency for Toxic Substances and Disease Registry, 1990). The frequency and severity of symptoms among exposed workers depend upon the level of exposure. Although much progress has been made in reducing lead exposures, exposures in the workplace continue to be a significant public health problem (Centers for Disease Control and Prevention, 1994).

Cadmium (Cd) is listed by the US Environmental Protection Agency as one of 126 priority pollutants. The most dangerous characteristic of cadmium is that it accumulates throughout a lifetime. Cadmium accumulates mostly in the liver and 
kidneys and has a long biological half-life of 17 to 30 years in humans (Hideaki et al., 2008). Cadmium's uses vary from an electrode component in alkaline batteries to a stabilizer in plastics. Although animal studies have shown that cadmium is a potent neurotoxicant, little is known about its toxicity for the human central nervous system (Viaene et al., 2000). Occupational exposure to cadmium is associated with cognitive impairment in adults. Cadmium interferes with several important nervous system functions, but the mechanisms of neurotoxicity remain uncertain (Hart et al., 1989).

Lead and cadmium induce clastogenic as well as aneugenic effects in peripheral lymphocytes, indicating a potential health risk for working populations with significant exposures to these heavy metals (Palus et al., 2003).

One of the major mechanisms behind heavy metal toxicity has been attributed to oxidative stress. Antioxidants such as selenium and vitamin $\mathrm{E}$ act to protect cells against the effects of free radicals, which are potentially damaging by-products of energy metabolism. Free radicals can damage cells and may contribute to the development of many human diseases (Van Gaal et al., 2006).

Selenium is an "essential" trace element, which has a variety of functions. It is a key component of several functional selenoproteins required for normal health. Whereas selenium is poisonous to man and animal in large amounts (De Lorgeril and Salen, 2006). Role of selenium as a protective against exposure to metals is a conflict issue. Most studies conclude that selenium has a beneficial role while few show no role (Hansen, 1988).

Vitamin E has also been shown to play a role in immune function, in DNA repair, and other metabolic processes (Farrell and Roberts, 1994). The antioxidant properties of vitamin E seemed to be responsible for protection from cadmium toxicity (Tandon et al., 1992) as well as iron-induced lipid perioxidation specially in combination with glutathione "GSH", and Nacetyl-cysteine "NAC" (Milchak and Douglas, 2002).

Co-exposure to cadmium, mercury, lead and other heavy metals occurs in many occupational settings, such as pigment and batteries production, galvanization and recycling of electric tools lamp factories. However, little is known about co-exposure to heavy metals.

This study aims to investigate the benefit of co-consumption of selenium and vitamin $\mathrm{E}$ either alone or in combination in case of co-exposure to mercury, lead and cadmium during working in a lamp factory. 
SUBJECTS, MATERIAL AND METHODS

\section{Subjects:}

The study was conducted on 56 subjects, 36 workers in a lamp factory at Monoufiya Governorate in Egypt (20 males and 16 females), ages ranged from 19-63 years, $(\mathrm{M}=29.5 \pm 10.12)$. Subjects were working for 0.5 to 40 years $(M=5.3 \pm 8.8)$ and 20 control subjects matched for age, gender, dietary habits, smoking, dental amalgam and life style with the workers. Subjects were classified as follows:

Group I : Control group (10 males and 10 females).

Group II: 36 factory workers divided into three subgroups $\mathrm{a}, \mathrm{b}$ and $\mathrm{c}$.

Group II a: 12 subjects ( 3 females and 9 males) received only selenium $100 \mu \mathrm{g}$ orally once daily before breakfast for 2 months.

Group II b: 12 subjects (6 females and 6 males) received only $100 \mathrm{mg}$ vitamin E orally once daily before breakfast for 2 months.

Group II c: 12 subjects (7 females and 5 males) received combination of selenium and vitamin $E$ with the same doses as mentioned in the previous groups, once daily before breakfast for 2 months.

\section{Material}

Selenium : $100 \mu \mathrm{g}$ tablet, 250 tablet yeast free, dietary supplement, vegetarian formula. Manufactured by NOW FOOD, BLOOMINGDALE, IL 60108, USA.

Vitamin E : 100mg capsule, 24 capsules, manufactured by Pharco.

\section{Methods :}

Blood sample collection: After taking written consent, venous radial blood samples were collected from each subject the day before starting medications, and at the end of research, as $2.5 \mathrm{ml}$ on sterile heparinized vacutainer tube and $5 \mathrm{ml}$ on sterile vacutainer plain tube. Separation of serum was done at the same day of sampling by centrifugation at $1500 \mathrm{rpm}$ for 15 minutes at $4^{\circ} \mathrm{C}$. Samples were preserved at $-20^{\circ} \mathrm{C}$ till conduction of analysis. The examination included blood samples analysis for determination of metals including, selenium, cadmium, mercury and lead. Serum levels of malondialdehyde (MDA), serum activity of catalase, and paraoxanse enzymes were also detected. Remeasuring metals and oxidative enzymes levels after 2 months treatment were done for the workers.

Heavy metal analysis: Selenium, lead, cadmium and mercury quantitative analysis was performed by means of micro analysis e.g. energy dispersive $\mathrm{X}$-ray fluorescence (EDXRF), a highly sensitive multi elemental method of micro-analysis. The EDXRF technique was chosen for its simplicity, accuracy, and sensitivity, as well 
as the samples do not need complex preparation. Plasma samples were collected and dried as powder being placed on KIMPOL polycarbonate film as a backing material previously mounted on a polyethylene target frame and fixed by $1 \%$ polystyrene in benzene. The samples collected by deposition on a filter paper and were put in an electric oven at $80^{\circ} \mathrm{C}$ for 4 days until dryness. The samples were grinded for full homogenization and very fine powder formation until analysis with Tube Excited X- ray Fluorescence Analysis apparatus (El Nimr et al., 1992).

\section{Biochemical analysis:}

1- Measurement of Serum PON1 ( paraoxonase) enzyme activity : PON1 activity was measured by adding $15 \mu \mathrm{l}$ serum to $285 \mu \mathrm{l}$ Tris buffer $(100 \mathrm{mmol} / \mathrm{L}, \mathrm{pH} 8.0)$ containing $2 \mathrm{mmol} / \mathrm{L} \mathrm{CaCL}_{2}$ and $1 \mathrm{mmol} /$ $\mathrm{L}$ paraoxon (O,O-diethyl-O-nitrophenylphosphate (Sigma Chemical Co.). The rate of generation of P-nitrophenol was determined at $405 \mathrm{~nm}, 25^{\circ} \mathrm{C}$ with the use of continuously recording spectrophotometer as described previously(Mackness et al.,1991)

\section{2- Measurement of Catalase (CAT) ac-} tivity: CAT was measured by determining the constant rate of hydrogen peroxide decomposition. The assay was performed according to the method described by Pifferi et al. (1981) with modifications as set forth by Nowak et al. (1997). The reaction mixture prepared in an Eppendorf tube consisted of $500 \mu \mathrm{L} 0.05 \mathrm{M}$ phosphate buffer (pH 7.0), $300 \mu \mathrm{L}$ distilled water, $50 \mu \mathrm{L}$ $1.1 \mathrm{mM} \mathrm{H}_{2} \mathrm{O}_{2}$ in distilled water, and $50 \mu \mathrm{L}$ serum sample (or $50 \mu \mathrm{L}$ distilled water as blank). After 5 minutes of incubation at $25^{\circ} \mathrm{C}, 100 \mu \mathrm{L} 50 \%$ trichloroacetic acid (Sigma Chemical) was added to each tube and the tubes were centrifuged $(1,000 \mathrm{~g}$ for 5 minutes). To each tube $10 \mu \mathrm{L}$ titanium (IV) reagent was added and $200 \mu \mathrm{L}$ supernatant was transferred into wells on a 96well micro plate. The absorbance was read at $405 \mathrm{~nm}$ in the micro plate reader. The results were expressed as CAT activity in units per milliliter of serum, after comparison with the standard curve. The standard curve was prepared by plotting the absorbance at $405 \mathrm{~nm}$ (ordinate) as a function of the standard CAT (Sigma Chemical) concentration between 0 to $33 \mathrm{U} / \mathrm{ml}$. One unit CAT decomposed $1 \mu$ mole $\mathrm{H}_{2} \mathrm{O}_{2}$ per minute at a $\mathrm{pH} 7.0$ and $25^{\circ} \mathrm{C}$.

\section{3- Measurement of malondialdehyde} (MDA) serum level: MDA was based on the coupling of MDA with thiobarbituric acid briefly, serum samples were diluted in phosphate buffer (20mM, pH7.4) and heated together with a thiobarbituric acid TBA solution $(375 \mathrm{mg} / \mathrm{ml})$ in a boiling water bath for $15 \mathrm{~min}$. The tubes were cooled, and the absorbance was measured by spectrophotometry at $535 \mathrm{~nm}$. 1,1,3,3Tetraethoxypropane. Sigma, St. Louis, MO was used as a stander (Bird and Draper, 1984). 
Medical and neurological examination:

The medical examination included a medical history, an evaluation of some behavioral and biological risk factors for cardiovascular disease (Marmot, 1988) and an evaluation of clinical neurological status: postural tremors of the upper extremities and a hand writing test, coordination, reflexes, the presence or absence of pathological reflexes, including snout reflex and pin pain sensation, touch pressure, two- point discrimination and vibratory sensation. Neurological examination was performed to detect complaints consistent with peripheral neuropathy and dysfunction of the autonomic nervous system.

Neuropsychological examination : All the workers were screened for the presence of psychiatric symptoms and / or disorders by General Health Questionnaire (GHQ-28), Arabic version (Godlberg and Hiller, 1979). GHQ-28 is widely used to screen populations for the presence of psychiatric illness. A number of validity studies indicate that GHQ is a reasonably sensitive and specific indicator of psychopathology (Marder, 1995).

The general health Questionnaire (GHQ-28) is a self-administered instrument, designed to detect four elements of distress : depression, anxiety, social impairment, and hypochondriasis.
(GHQ-28) consists of four subscale items:

A- Somatic symptoms

B- Anxiety and insomnia.

C- Social dysfunction.

D- Depression.

The scoring method was 0-0-1-1 for all 28 items, for each symptom in each group a total score of 5 or more indicates the presence of the symptom, while below 5 score means no symptoms (Goldberg et al., 1997).

The (GHQ-28) was distributed to the studied subjects at their work settings. The educated subjects take usually 15 -25 minutes to complete the GHQ. The examiner helped the non- educated subjects. After that, the data were collected for analysis.

\section{RESULTS}

\section{I- Results of metal analysis by energy dispersive X-ray fluorescence (EDXRF):}

It was found that there is significant elevation in blood concentrations of mercury, cadmium and lead in factory workers $(1.576 \pm 0.26,1.77 \pm 0.344$ and $0.3831 \pm 0.0669$ respectively), when compared with control subjects $(0.234 \pm 0.026,1.223 \pm 0.0709$, and $0.245 \pm 0.035$ respectively) (Table 1 ).

No significant changes were observed in different age groups or between both 
sexes in the factory workers group in blood metal levels (Tables 2-3).

Regarding the duration of exposure of the workers, which ranges from 6 months to 40 years, it was noticed that there was so significant changes in different durations of exposure (Table 4). Following treatment by selenium and vitamin E, there was significant decrease in blood levels of $\mathrm{Hg}, \mathrm{Cd}$ and $\mathrm{Pb}$ when compared with the same workers before treatment (Table 5). As regards type of treatment they received, no significant differences were noticed between different groups (Table 6).

\section{II- Results of biochemical analysis:}

As regards the biochemical results, there is significant decrease in serum CAT and PON1 activity and increase in serum MDA level in the exposed workers in comparison with the control group (Table 7). Following treatment with selenium and vitamin E, there was significant increase in serum CAT and PON1 and decrease in serum MDA level in workers after 2 months treatment in comparison with themselves before treatment (Table 8).

\section{III- Results of the neuropsychological evaluation: \\ A- The General Health Questionnaire (GHQ):}

Using the general health questionnaire, it was found that anxiety, insomnia and depression were significantly noticed among workers, and no significant differences as regards social dysfunction and somatic symptoms in comparison with control group (Table 9).

\section{B- Cognitive tests:}

Cognitive tests revealed significant deterioration in short term memory, perceptual ability, short term visual memory as well as in trail making test in comparison with the control group, while no significant differences were detected as regards long term memory (Table 10).

\section{DISCUSSION}

Metal induced toxicity is very well reported in the literature. A growing amount of data provide evidence that metals are capable of interacting with nuclear proteins and DNA causing oxidative deterioration of biological macromolecules (Leonard et al., 2004).

Normal levels of mercury, cadmium and lead in blood are $<0.04 \mathrm{mg} / 1,0.1-0.4$ $\mathrm{ug} / \mathrm{l}$ and 0.1-0.4 $\mathrm{mg} / \mathrm{l}$ respectively (Gothe, 1985; Roper, 1991 and Young-Jin, 2006). This means that mercury, cadmium and lead blood levels in the current study both in the control group and the factory workers group were above the normal levels, whereas in workers were significantly higher than the control. This was associat- 
ed with significant decrease in serum CAT and PON1 activity and increase in serum MDA levels as well as higher incidence of neuropsychiatric disorders in the factory workers in comparison with the control. The elevated levels of the mercury, cadmium and lead may posed these neuropsychiatric disorders.

A number of researchers have also shown enhanced rate of lipid peroxidation in brain of lead exposed rats (Adegbesan and Adenuga, 2007 and Bokara et al., 2008). One of the suggested mechanisms is inhibition of d-aminolevulinic acid dehydratase (ALAD). There was an excessive production of n-NOS (neural nitric oxide synthase) and MAO (mono-amino oxidase), depletion of GABA, 5HT and AchE, which are important neurotransmitters that control neurobehavioral changes (Flora et al., 2007).

Several studies have shown that lead alters the activity of antioxidant enzymes like superoxide dismutase (SOD), catalase, glutathione peroxidase (GPx) and glucose 6-phosphate dehydrogenase (G6PD) and antioxidant molecules like GSH in animals, and human beings (Gurer and Ercal, 2000).

Whanger (1992) reported that selenium is essential for GPx activity, and lead forms a complex with selenium, thereby decreases its activity.
Galan et al. (2001) showed that cadmium, unlike other heavy metals is unable to generate free radicals by itself, however, reports have indicated superoxide radical, hydroxyl radical and nitric oxide radicals could be generated indirectly

Watanabe et al. (2003) showed generation of non-radical hydrogen peroxide which by itself became a significant source of free radicals via the Fenton chemistry.

Numerous reports on animal models have depicted that cadmium intoxication significantly increased the malondialdehyde (MDA) and glutathione peroxidase (GSH-Px) (Yang et al., 2003; Cosic et al., 2007).

Neuronal inhibition by $\mathrm{CdCl}$-induced oxidative stress is a new mechanism of cadmium action which may directly produce neurotoxic symptoms as well as implicate cadmium and related metals as environmental factors in the etiology of neurodegenerative diseases (Monroe and Halvorsen, 2006).

Mahboob et al. (2001) showed that when mice were exposed to mercuric chloride, there were alterations in the lipid peroxidation (LPO), glutathione reductase (GR), glutathione peroxidase (GPx), superoxide dismutase (SOD) and GSH levels in different organs. Toxic effects of mercury have also been observed 
in oligodendrocytes, astrocytes, cerebral cortical and cerebellar granular neurons obtained from embryonic and neonatal rat brains (Yee and Choi, 1996).

However, Peter et al. (2002) concluded that oxidative stress and changes in GSH and activities of antioxidant enzymes do not play a major role in $\mathrm{Hg}$ vapor toxicity in brain and kidney. Exposure to low levels of mercury vapor has been associated with impairment of neurobehavioral function.

Some studies concluded that there was no strong evidence that blood mercury levels are associated with worse neurobehavioral performance in older urban adult (Mutter and Naumann, 2005 and Weil et al., 2005).

The biochemical results in our study revealed significant decrease in serum CAT and PON1 activity and increase in serum MDA level in the exposed workers in comparison with the control group.

The production of malondialdehyde is used as a biomarker to measure the level of oxidative stress in an organism (Del Rio et al., 2005). Elevation of its level is an indication of oxidative stress exposure.

The protective role of paraoxonase against lipoprotein lipid peroxidation was suggested to be related to the ability of PON1 to hydrolyze oxidized lipids including oxidized phospholipids and cholesteryl ester hydroperoxides (Aviram et al., 1999). Compounds (from diet or drugs) with antioxidative activity against lipoprotein oxidation preserved PON1 activity, in association with their ability to protect lipoproteins against oxidation (Aviram et al., 2000).

Catalase is a common enzyme found in nearly all living organisms which are exposed to oxygen, where it functions to catalyze the decomposition of hydrogen peroxide to water and oxygen (Chelikani et al., 2004).

The protective effect of selenium against lead toxicity may be attributed to a competition between selenium and lead for binding with the functional bioligands or to the in vivo formation of lead selenide (Flora et al., 1983). It is known that the oxidation- reduction processes of mercury and selenium play a mediated role in the accumulation of inorganic mercury in tissue and its loss from tissue cells (Clarkson and Kilpper, 1978; Magos, 1991). This can explain the decrease in blood lead and mercury level following treatment by selenium in the current study.

Experimental studies conducted on the protective effect of selenium against the 
hepatotoxicity and renal toxicity of cadmium concluded that selenium could have a protective effect by its antioxidant effect which counter the oxidative stress induced by cadmium that may cause its hepatotoxic and nephrotoxic effects (El-Sharaky et al., 2007; Newairy et al., 2007).

Vitamin-E could be useful in order to protect membrane-lipids and, notably, to prevent protein oxidation produced by lead intoxication. It has been claimed that $\alpha$-tocopherol is the most important lipidsoluble antioxidant, and that it protects cell membranes from oxidation by reacting with lipid radicals produced in the lipid peroxidation chain reaction (RendonRamirez et al., 2007; Traber and Atkinson, 2007).

This would remove the free radical intermediates and prevent the oxidation reaction from continuing. Vitamin $\mathrm{E}$ has a greater effect than selenium in reducing lipid peroxidation in various brain regions (Whanger, 2001).

Reports have shown that antioxidants like vitamin $C$ and Vitamin $E$ have shown protection against cadmium induced toxicity in different animal models (Ognjanovic et al., 2003 and Beytut et al., 2003 ). Cosic et al. (2007), showed that presence of antioxidants like cysteine, glutathione and ascorbate induced more DNA damage in in-vitro experiments. This DNA damage was considered to be due to the generation of reactive species. Experimental studies explore the protecting effect of vitamin $\mathrm{E}$ and selenium either alone or in combination against the toxic metal effects especially cadmium, mercury and lead (Beyrouty and Chan, 2006) which agrees with the current study.

The higher incidence of neuropsychiatric disorders observed in the workers in comparison with control may be mediated by the oxidative stress caused by mercury, cadmium, and lead. Decrement in this oxidative stress occurs after treatment by selenium and vitamin $\mathrm{E}$ and was measured by significant increase in serum CAT and PON1 activity and decrease in serum MDA level following treatment. As the controls also have high levels of metals, so it may be related to the increased incidence of neuropsychiatric disorders among non-exposed population, so selenium with vitamin E could play a role in decreasing incidence of these disorders.

It could be concluded that supplemental consumption of selenium or vitamin E by workers occupationally exposed to lead, cadmium and mercury could protect against neurobehavioral disorders that could appear along chronic exposure. 
Table (1): Comparison between blood levels of mercury, cadmium and lead of the control group and the factory workers group.

\begin{tabular}{|l|c|c|c|c|}
\hline & $\begin{array}{c}\text { Factory workers } \\
\text { group } \\
(\mathbf{n = 3 6})\end{array}$ & $\begin{array}{c}\text { Control group } \\
(\mathbf{n = 2 0})\end{array}$ & \multirow{2}{*}{$\mathbf{t}$} & \\
\cline { 2 - 4 } & Mean $\pm \mathbf{S E}$ & Mean \pm SE & & \\
\hline Hg $(\mathrm{mg} / \mathrm{l})$ & $1.576 \pm 0.26$ & $0.234 \pm 0.026$ & -30.66 & $0.000^{*}$ \\
\hline $\mathbf{C d}(\mathrm{ug} / \mathrm{l})$ & $1.77 \pm 0.344$ & $1,223 \pm 0.0709$ & -8.82 & $0.000^{*}$ \\
\hline $\mathbf{P b}(\mathrm{mg} / \mathrm{l})$ & $0.3831 \pm 0.0669$ & $0.245 \pm 0.035$ & -10.06 & $0.000^{*}$ \\
\hline
\end{tabular}

*Significant difference $(\mathrm{p}<0.05)$

Table (2): Comparison between blood metal levels of different age groups.

\begin{tabular}{|l|l|l|l|}
\hline Age group & Mean $\mathbf{H g} \pm \mathbf{S E}$ & Mean $\mathbf{P b} \pm \mathbf{S E}$ & Mean Cd $\pm \mathbf{S E}$ \\
\hline$<30$ Y $(\mathbf{n = 2 6})$ & $1.602 \pm 0.054$ & $0.386 \pm 0.014$ & $1.743 \pm 0.066$ \\
\hline$>\mathbf{3 0}$ Y $(\mathbf{n = 1 0})$ & $1.509 \pm 0.067$ & $0.374 \pm 0.014$ & $1.755 \pm 0.12$ \\
\hline $\mathbf{T}$ & 1.08 & 0.61 & 0.08 \\
\hline $\mathbf{P}$ & 0.293 & 0.546 & 0.936 \\
\hline
\end{tabular}

*Significant difference $(\mathrm{p}<0.05)$

Table (3): Comparison between blood metal levels of both sexes.

\begin{tabular}{|l|l|l|l|}
\hline Sex & Mean Hg \pm SE & Mean $\mathbf{P b} \pm \mathbf{S E}$ & Mean Cd \pm SE \\
\hline \multirow{O}{}{$(\mathbf{n}=\mathbf{2 0})$} & $1.611 \pm 0.06$ & $0.373 \pm 0.011$ & $1.831 \pm 0.096$ \\
\hline$+(\mathbf{n}=\mathbf{1 6})$ & $1.532 \pm 0.063$ & $0.395 \pm 0.021$ & $1.641 \pm 0.035$ \\
\hline $\mathbf{T}$ & 0.91 & 0.91 & 1.85 \\
\hline $\mathbf{P}$ & 0.371 & 0.373 & 0.078 \\
\hline
\end{tabular}

*Significant difference $(\mathrm{p}<0.05)$ 
Table (4): Comparison between blood metal levels in different durations of exposure.

\begin{tabular}{|l|c|c|c|}
\hline Duration of Exposure & Mean $\mathbf{H g} \pm \mathbf{S E}$ & Mean $\mathbf{P b} \pm \mathbf{S E}$ & Mean $\mathbf{C d} \pm \mathbf{S E}$ \\
\hline $\mathbf{0 . 5} \boldsymbol{-} \mathbf{2}$ ys $(\mathbf{n}=\mathbf{2 0})$ & $1.578 \pm 0.054$ & $0.397 \pm 0.016$ & $1.697 \pm 0.067$ \\
\hline$>\mathbf{2 - 5}$ ys $(\mathbf{n}=\mathbf{9})$ & $1.68 \pm 0.1$ & $0.382 \pm 0.022$ & $1.918 \pm 0.17$ \\
\hline$>\mathbf{5 - 1 0}$ ys $(\mathbf{n}=\mathbf{5})$ & $1.388 \pm 0.11$ & $0.346 \pm 0.019$ & $1.652 \pm 0.032$ \\
\hline$>\mathbf{1 0}$ ys $(\mathbf{n}=\mathbf{2})$ & $1.565 \pm 0.11$ & $0.34 \pm 0.02$ & $1.705 \pm 0.015$ \\
\hline P value & 0.262 & 0.369 & 0.393 \\
\hline
\end{tabular}

*Significant difference $(\mathrm{p}<0.05)$

Table (5): Comparison between blood levels of mercury, cadmium and lead in the factory workers before and after treatment with selenium and vitamin $\mathrm{E}$.

\begin{tabular}{|l|c|c|c|c|}
\hline & $\begin{array}{c}\text { Factory workers group } \\
\text { before treatment }\end{array}$ & $\begin{array}{c}\text { Factory workers group } \\
\text { after treatment }\end{array}$ & \multirow{2}{*}{$\mathbf{t}$} & \multirow{P}{*}{} \\
\cline { 2 - 4 } & Mean \pm SE & Mean \pm SE & & \\
\hline $\mathbf{H g}$ & $1.576 \pm 0.26$ & $1.231 \pm 0.194$ & 6.38 & $0.000^{*}$ \\
\hline $\mathbf{C d}$ & $1.77 \pm 0.344$ & $1.366 \pm 0.209$ & 5.68 & $0.000^{*}$ \\
\hline $\mathbf{P b}$ & $0.3831 \pm 0.0669$ & $0.2967 \pm 0.0464$ & 6.37 & $0.000^{*}$ \\
\hline
\end{tabular}

*Significant difference $(\mathrm{p}<0.05)$

Table (6): Comparison between blood metal levels in the factory workers as regards type of treatment.

\begin{tabular}{|l|c|c|c|c|}
\hline Type of treatment & No. & Mean $\mathbf{H g} \pm \mathbf{S E}$ & Mean $\mathbf{P b} \pm \mathbf{S E}$ & Mean Cd $\pm \mathbf{S E}$ \\
\hline Vit. E (n=12) & $\mathbf{1 2}$ & $1.612 \pm 0.097$ & $0.367 \pm 0.014$ & $1.769 \pm 0.1$ \\
\hline Selenium (n=12) & $\mathbf{1 2}$ & $1.520 \pm 0.075$ & $0.398 \pm 0.024$ & $1.729 \pm 0.11$ \\
\hline $\begin{array}{l}\text { Both Vit. E and } \\
\text { Selenium (n=12) }\end{array}$ & $\mathbf{1 2}$ & $1.595 \pm 0.05$ & $0.383 \pm 0.019$ & $1.742 \pm 0.1$ \\
\hline P value & & 0.668 & 0.542 & 0.961 \\
\hline
\end{tabular}

*Significant difference $(\mathrm{p}<0.05)$ 
Table (7) : Comparison between serum levels of CAT, PON1 activity and MDA level between factory workers and the control group.

\begin{tabular}{|c|c|c|c|c|}
\hline & $\begin{array}{c}\text { Factory workers } \\
\text { group }(\mathbf{n = 3 6})\end{array}$ & $\begin{array}{c}\text { Control group } \\
(\mathbf{n = 2 0})\end{array}$ & $\mathbf{t}$ & $\mathbf{P}$ \\
\hline Serum Catalase (U/ml) & $10.3 \pm 2.45$ & $16.45 \pm 5.07$ & 5.11 & $0.000^{*}$ \\
\hline MDA ( nmol/ml) & $5.6 \pm 0.6$ & $2.2 \pm 0.4$ & 24.8 & $0.000^{*}$ \\
\hline Paraoxonase (U/ml) & $23.3 \pm 7.7$ & $39.7 \pm 14.4$ & -4.7 & $0.000^{*}$ \\
\hline
\end{tabular}

*Significant difference $(\mathrm{p}<0.05)$

Table (8): Comparison of serum levels of CAT, PON1 activity and MDA level in the factory workers group before and after treatment with selenium and vitamin $\mathrm{E}$.

\begin{tabular}{|l|c|c|c|c|}
\hline & $\begin{array}{c}\text { Factory workers } \\
\text { group before } \\
\text { treatment }(\mathbf{n}=36)\end{array}$ & $\begin{array}{c}\text { Factory workers } \\
\text { group after } \\
\text { treatment }(\mathbf{n = 3 6})\end{array}$ & $\mathbf{t}$ & $\mathbf{p}$ \\
\hline Serum Catalase & $10.3 \pm 2.45$ & $15.21 \pm 4.1$ & 6.17 & $0.000^{*}$ \\
\hline MDA & $5.6 \pm 0.6$ & $3.2 \pm 0.3$ & -19.4 & $0.000^{*}$ \\
\hline Paraoxonase & $23.3 \pm 7.7$ & $44.6 \pm 70.4$ & -1.8 & 0.080 \\
\hline
\end{tabular}

*Significant difference $(\mathrm{p}<0.05)$

Table (9): Results of the General Health Questionnaire (GHQ).

\begin{tabular}{|c|c|c|c|c|c|c|}
\hline \multirow[t]{2}{*}{ GHQ results } & \multicolumn{2}{|c|}{$\begin{array}{l}\text { Factory workers } \\
\text { group before } \\
\text { treatment } \\
(\mathbf{n}=\mathbf{3 6})\end{array}$} & \multicolumn{2}{|c|}{$\begin{array}{l}\text { Control group } \\
\qquad(\mathbf{n}=20)\end{array}$} & \multirow[t]{2}{*}{$\mathbf{X}^{2}$} & \multirow[t]{2}{*}{$\mathbf{P}$} \\
\hline & n. & $\%$ & n. & $\%$ & & \\
\hline Anxiety-insomnia & 16 & $44.44 \%$ & 4 & $11.11 \%$ & 9.97 & $0.002 *$ \\
\hline Depression & 19 & $52.78 \%$ & 7 & 19.44 & 8.67 & $0.003 *$ \\
\hline Social dysfunction & 15 & $41.67 \%$ & 8 & $22.22 \%$ & 3.13 & 0.08 \\
\hline Somatic symptoms & 8 & $22.22 \%$ & 5 & $13.89 \%$ & 0.08 & 0.8 \\
\hline
\end{tabular}


Table (10): Comparison between control group and factory workers before treatment as regards cognitive tests.

\begin{tabular}{|l|c|c|c|c|}
\hline & $\begin{array}{c}\text { Factory workers } \\
\text { before treatment } \\
(\mathbf{n . = 3 6})\end{array}$ & $\begin{array}{c}\text { Control group } \\
(\mathbf{n .}=36)\end{array}$ & $\mathbf{t}$ & $\mathbf{P}$ \\
\hline $\begin{array}{l}\text { Information } \\
\text { (Long-term memory) }\end{array}$ & $12 \pm 3.95$ & $12.94 \pm 4.57$ & 1.27 & 0.2 \\
\hline $\begin{array}{l}\text { Digit span } \\
\text { (Short-term memory) }\end{array}$ & $7.33 \pm 3.09$ & $9.14 \pm 3.56$ & 3.75 & $0.001^{*}$ \\
\hline $\begin{array}{l}\text { Digit symbol } \\
\text { (Perceptual ability) }\end{array}$ & $12.19 \pm 5.50$ & $14.19 \pm 6.83$ & 2.37 & $0.02^{*}$ \\
\hline Bender Gestalt \\
$\begin{array}{l}\text { (Short-term visual } \\
\text { memory) }\end{array}$ & $17.44 \pm 2.34$ & $16 \pm 1.66$ & 3.64 & $0.001^{*}$ \\
\hline Trail Making (A) & $50.22 \pm 12.65$ & $54.86 \pm 15.79$ & 2.78 & $0.009^{*}$ \\
\hline
\end{tabular}

*Significant difference $(\mathrm{p}<0.05)$ 


\section{REFERENCES}

Adegbesan, B. O. and Adenuga, G. A. (2007) : "Effect of lead exposure on liver lipid peroxidative and antioxidant defense systems of protein-undernourished rats". Biol. Trace Elem. Res., 116: 219-225.

Agency for Toxic Substances and Disease Registry (ATSDR). (1990) : Toxicological profile for lead. Atlanta, GA: Cincinnati, OH: U.S. Department of Health and Human Services, ATSDR Publication No. 88/17.

Aviram, M.; Rosenblat, M.; Billecke, S.; et al. (1999) : "Human serum paraoxonase (PON 1) is inactivated by oxidized low density lipoprotein and preserved by antioxidants". Free Radic. Biol. Med., 26:892-904.

Aviram, M.; Dorenfel, L.; Rosenblat, M.; et al. (2000) : "Pomegranate juice consumption reduces oxidative stress, low density lipoprotein modifications and platelet aggregation: studies in the atherosclerotic apolipoprotein $\mathrm{E}$ deficient mice and in human". Am. J. Clin. Nutr., 71:1-15.

Beyrouty, P. and Chan, H. M. J. (2006) : "Co-consumption of selenium and vitamin $\mathrm{E}$ altered the reproductive and developmental toxicity of methylmercury in rats". Neurotoxicol. Teratol., 28(1):49-58.
Beytut, E.; Yuce, A.; Kamiloglu, N. N. and Aksakal, M. (2003) : "Role of dietary vitamin $\mathrm{E}$ in cadmium-induced oxidative damage in rabbit's blood, liver and kidneys". Int. J. Vitam. Nutr. Res., 73 : 351355.

Bird, P. and Draper, H. (1984) : "Comparative study on different methods of malonaldehyde determination". Methods Enzymol., 105:299-305.

Bokara, K. K.; Brown, E., McCormick, R.; Yallapragada, P. R.; Rajanna, S. and Bettaiya, R. (2008) : "Lead-induced increase in antioxidant enzymes and lipid peroxidation products in developing rat brain". Biometals., 21: 9-16.

Centers for Disease Control and Prevention (CDC) (1994) : "Adult blood lead epidemiology and surveillance - United States, fourth quarter". MMWR., 44(14): 286-287.

Chelikani, P.; Fita, I. and Loewen, P. C. (2004) : "Diversity of structures and properties among catalases". Cell. Mol. Life Sci. 61 (2): 192-208.

Clarkson, T. W. and Kilpper, R. W. (1978 ): The Metabolism of Inhaled Vapor as Environmental Hazards to Man. Environmental Health Sciences Center Program Project. Rochester, New York, P. 449. 
Cosic, D. D.; Bulat, Z. P.; Ninkovic, M.; Malicevic, Z. and Matovic, V. (2007) : "Effect of subacute cadmium intoxication on iron and lipid peroxidation in mouse liver". Toxicol. Lett., 172 : 209.

De Lorgeril, M. and Salen, P. (2006) : "Selenium and antioxidant defenses as major mediators in the development of chronic heart failure". Heart Fail. Rev., 11 (1):13-17.

Del Rio, D.; Stewart, A. J. and Pellegrini, N. (2005) : "A review of recent studies on malondialdehyde as toxic molecule and biological marker of oxidative stress". Nutr. Metab. Cardiovasc. Dis., 15 (4): 316328.

El Nimr, T.; El Enary, N. and Ali, A. (1992) : "EDXRF Multi elemental method of micro analysis". Egy. J. Phys., 22 : $1-2$.

El-Sharaky, A. S.; Newairy, A. A.; Badreldeen, M. M.; Eweda, S. M. and Sheweita, S. A. (2007) : "Protective role of selenium against renal toxicity induced by cadmium in rats". Toxicology, 235(3): 185193.

Farrell, P. and Roberts, R. (1994) : "Vitamin E." In: Nutrition in Health and Disease. Shils, M.; Olson, J.A., and Shike, M. (Eds.), Modern 8th ed.: Lea and Febiger, Philadelphia, PA, P.326.
Flora, S. J.; Singh, S. and Tandon, S. K. (1983) : "Role of selenium in protection against lead intoxication". Acta Pharmacol. Toxicol., 53(1):28-32.

Flora, S. J. S.; Saxena, G. and Mehta, A. (2007) : "Reversal of lead-induced neuronal apoptosis by chelation treatment in rats: role of ROS and intracellular Ca2+". J. Pharmacol. Exp. Ther., 322 : 108116.

Galan, C.; Garcia, B. L.; Troyano, A.; Vilaboa, N. E.; Fernandez, C.; Blas, D. E.; et al. (2001): "The role of intracellular oxidation in death induction (apoptosis and necrosis) in human promonocytic cells treated with stress inducers (cadmium, heat, X-rays)". Eur. J. Cell Biol., 80 : 312320.

Goldberg, D. P. and Hiller, V. F. (1979) : "A scaled version of the General Health Questionnaire". Psychological Medicine, 9 : 139-145.

Goldberg, D.; Gater, R.; Sartorius, N.; Ustun, T.; Piccinelli, M.; Gureje, O.; et al. (1997) : "The validity of two versions of the GHQ in the WHO study of mental illness in general health care". Psychological Medicine, 27(1) : 191-197.

Goldwater, L. J. (1972) : Mercury: A History of Quicksilver. Baltimore, New Press. 
Gothe, D. J. (1985) : "Biological monitoring of exposure to metallic mercury". Clin. Toxicol., 23:381.

Gurer, H. and Ercal, N. (2000) : "Can antioxidants be beneficial in the treatment of lead poisoning?". Free Radical Biol. Med., 29: 927-945.

Hansen, J. C. (1988) : "Has selenium a beneficial role in human exposure to inorganic mercury?". Med. Hypotheses, 25 (1):45-53.

Hart, R. P.; Rose, C. S. and Hamer, R. M. (1989) : "Neuropsychological effects of occupational exposure to cadmium". J. Clinical and Experimental neuropsychology, 11(6): 933-943.

Hideaki, S.; Yasutake, A.; Hirashima, T.; Takamure, Y.; Kitano, T.; Waalkes, M. P.; et al. (2008) : "Strain difference of cadmium accumulation by liver slices of inbred Wistar-Imamichi and Fischer 344 rats". Toxicology in Vitro, 22: 338-343.

Leonard, S. S.; Harris, G. K. and Shi, X. L. (2004) : "Metal-induced oxidative stress and signal transduction". Free Rad. Biol. Med., 37: 1921-1942.

\section{Mackness, M. I.; Harty, D.; Bhatna-} gar, D.; et al. (1991) : "Serum paraoxonase activity in familial hypercholesterolaemia and insulin dependent dia- betes mellitus". Atherosclerosis, 86 : 193199.

Magos, L. (1991) : Overview on the protection given by selenium againsl mercurials. In : Advances in Mercury Toxicology. Suzuki et al., (Eds.), Plenum Press, New York, P.P. 289-298.

Mahboob, M.; Shireen, K. F.; Atkinson, A. and Khan, A. T. (2001) : "Lipid peroxidation and antioxidant enzyme activity in different organs of mice exposed to low level of mercury". J. Environ. Sci. Health, 36 : 687-697.

Marder, S. R. (1995) : Psychiatric rating scales. In : Comprehensive Textbook of Psychiatry. Kaplan, H.I. and Sadock, B.J. (Eds.), Williams and Wilkins, P.P. 619-635.

Marmot, M. G. (1988) : "Psychosocial factors and cardiovascular disease: epidemiological approaches". Europ. H. J., 9 : 690-697.

Milchak, L. M. and Douglas Bricker, J. (2002) : "The effects of glutathione and vitamin $\mathrm{E}$ on iron toxicity in isolated rat hepatocytes". Toxicol. Lett., 126 (3) : 169177.

Monroe, R. K. and Halvorsen, S. W. (2006) : "Cadmium blocks receptormediated Jak/STAT signaling in neurons 
by oxidative stress" Free Radical Biology \& Medicine, 41(3): 493-502.

Mutter, J. and Naumann, J. (2005) : "Blood Mercury Levels and Neurobehavior". JAMA, 294: 679.

Newairy, A. A.; El-Sharaky, A. S.; Badreldeen, M. M.; Eweda, S. M. and Sheweita, S. A. (2007) : "The hepatoprotective effects of selenium against cadmium toxicity in rats". Toxicology, 242(1-3):23-30.

Nowak, G.; Nowak, M.; Matuszewska, A. and Malarczyk, E. (1997) : "Activities of selected oxidases in idiophasic cultures of Trametes versicolor and Pleurotus eryngii". Biological Sciences Symposium 1 : 397-400.

Ognjanovic, B. I.; Pavlovic, S. Z.; Maletic, S. D.; Zikic, R. V.; Stajn, A. S.; Radojicic R. M.; et al. (2003) : "Protective influence of vitamin $\mathrm{E}$ on antioxidant defense system in the blood of rats treated with cadmium". Physiol. Res., 52 : 563-570.

Palus, J.; Rydzynsk, K.; Dziubaltowska, E.; Wyszynska, K.; Natarajan, A. T. and Nilsson, R. (2003) : "Genotoxic effects of occupational exposure to lead and cadmium mutation research". Genetic Toxicology and Environmental Mutagenesis, 540 (1): 19-28.

Peter, L. G.; Daniel, L. M. and Syed, F.
A. (2002) : "Effects of mercury vapor inhalation on reactive oxygen species and antioxidant enzymes in rat brain and kidney are minimal" J. Applied Toxicology, 22 (3):167- 172.

Pifferi, P. G.; Lanserini, G. and Biancani, M. (1981) : "Glucose oxidase determination by means of the formation of the hydrogen peroxide-titanium complex". Ann. Di. Chim.,18:729.

Quig, D. (1998) : "Cysteine metabolism and metal toxicity". Altern. Med. Rev., 3 (4): 262-270.

Rendon-Ramirez, A.; CerbonSolorzano, J.; Maldonado-Vega, M.; Quintanar-Escorza, M. A. and CalderonSalinas, J. V. (2007) : "Vitamin-E reduces the oxidative damage on $\delta$-aminolevulinic dehydratase induced by lead intoxication in rat erythrocytes". Toxicology In Vitro, 21: 1121-1126.

Roper, W. L. (1991) : Preventing lead poisoning in young children: A statement by the centers for disease control. Atlanta, GA: U.S. Department of Health and Human services, Public Health Service.

Smith, D. L. (1978) : "Mental effects of mercury poisoning". South Med. J., 71 : 904-905.

Tandon, S. K.; Singh, S. and Dhawan, 
M. (1992) : "Preventive effect of vitamin E in cadmium intoxication". Biomed. Environ. Sci., 5(1): 39-45.

Traber, M. G. and Atkinson, J. (2007) : "Vitamin E, antioxidant and nothing more". Free Radic. Biol. Med., 43 (1): 415.

Van Gaal, L.; Mertens, I. and De Block, C. (2006) : "Mechanisms linking obesity with cardiovascular disease". Nature, 444 (7121): 875-880.

Viaene, M.; Masschelein, R.; Leenders, J.; De Groof, M.; Swerts, L. and Roels, H. (2000): "Neurobehavioural effects of occupational exposure to cadmium: a cross sectional epidemiological study". Occup. Environ. Med., 57(1): 19-27.

Watanabe, M.; Henmi, K.; Ogawa, K. and Suzuki, T. (2003) : "Cadmiumdependent generation of reactive oxygen species and mitochondrial DNA breaks in photosynthetic and non-photosynthetic strains of Euglena gracilis". Comp. Biochem. Physiol. Toxicol. Pharmacol., 134 : 227-234.

Weil, M.; Bressler, J.; Parsons, P.;
Bolla, K.; Glass, T. and Schwartz, B. (2005) : "Blood mercury levels and neurobehavioral function". JAMA, 293 : 18751882.

Whanger, P. D. (1992) : "Selenium in the treatment of heavy metals poisoning and chemical carcinogenesis". J. Trace. Elem. Elect., 6: 209-221.

Whanger, P. D. (2001) : "Selenium and the brain: a review". Nutr. Neurosci., 4 (2): 81-97.

Yang, J. M.; Arnush, M.; Chen, Q. Y.; Wu, X. D.; Pang, B. and Jiang, X. Z. (2003) : "Cadmium-induced damage to primary cultures of rat Leydig cells". Reprod. Toxicol., 17: 553-560.

Yee, S. and Choi, B. H. (1996) : “Oxidative stress in neurotoxic effects of methyl mercury poisoning". Neurotoxicology, 17 : 17-26.

Young-Jin, S. (2006) : Mercury. In: Goldfrank's Toxicologic Emergencies. Flomenbaum. N. E.; Goldfrank, L. R.; Hoffman, R. S.; Howland, M. A.; et al. (Eds.), 8th ed. The McGraw-Hill Companies, New York. P.96. 


\title{
دور السيلينيام وويتامين هـ فـى حالة التعرض الههنس للهعادن الثقيلة

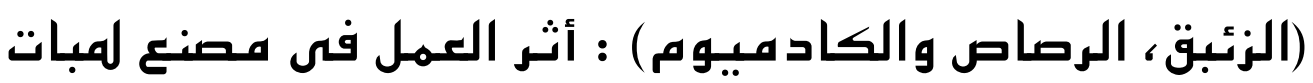

\author{
المثتركون فى البحث

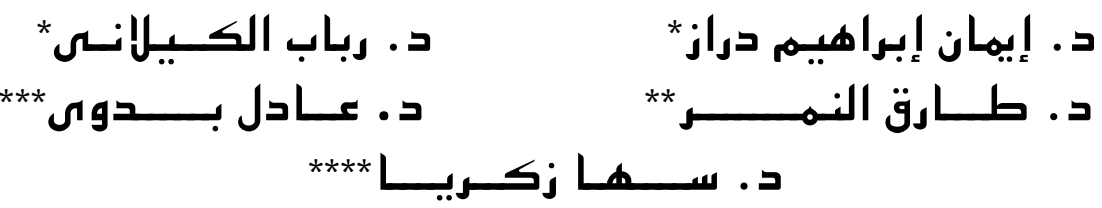

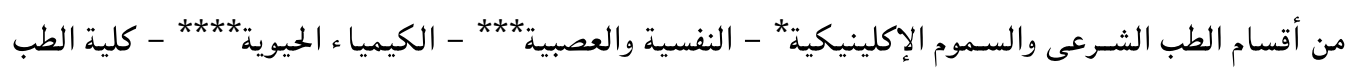

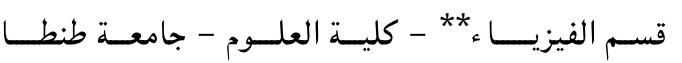

المعادن الثقيلة هى ملوثات بيئية تسبب تأثيرات صحية طويلة المدى، ولسوء الحظ أن هناك قصور فى تنفيذ الإجراءات الواقية ممايؤدى إلى تأثيرات سلبية خطيرة على القطاع المتعرض. الهدف من هذا البحث هو تحديد ما إذا كان تناول المكملات الغذائية مثل السيلينيام وثيتامين هـ قد يعالج التأثيرات الضارة نتيجة للتعرض المتزامن لكل من الرصاص والزئبق والكادميوم، وقد تم عمل الدراسة على ؟ب عامل بصنع لمبات،

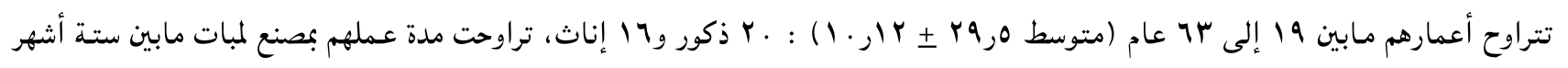
إلى أربعين عـام (متوسط = 0,0

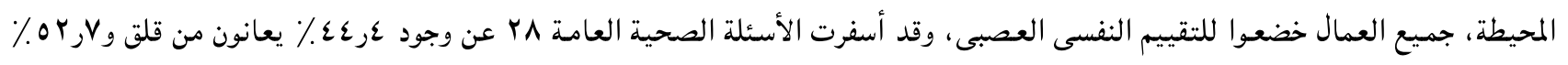

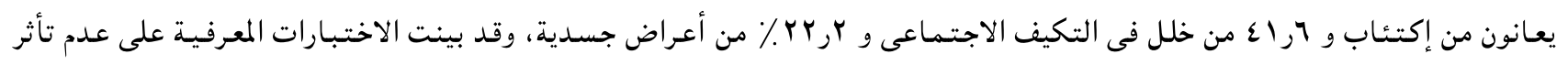
الذاكرة البعيدة بالمقارنة بالمجموعة الضابطة ولكن تأثرت الذاكرة القريبة والقدرة على الإدراك الحسى، كذلك تم قياس مستويات المعادن بالدم بجهاز (EDXR) وقد بينت نتائج التحليل أن متوسط تركيز كل من الزئبق والرصاص والكادميوم قبل العلاج كانت مرتفعة إرتفاعاً ذو دلالة إحصائية، وقد انخفضت هذه المستويات إنخفاضاً ذو دلالة إحصائية بعد تناول كل من السيلينيام وفيتامين هـ. أما بالنسبة لإنزيمات مضادات الأكسدة وتتضمن باروكسينيز وكتاليز ومالوندالدهايد فقد تم قياسها قبل وبعد العلاج وذلك بعد مقارنتها قبل العلاج بالمجموعة الضابطة وقد 
وجد أن هناك تحسن فى النشاط المضاد للأكسدة، وعلى ضوء هذه النتائج نتبين أن تناول كل من السيلينيام وفيتامين هـ منفردين أو مجتمعين يسـاعـد على خـفض مستــويات كل من الزئبق والرصـاص والكادمـيـام فى الدم وتحسين النشـاط المضاد للأكسـدة الذى من الممكن أن يعـالج الاضطرابات النفسية العصبية الحادثة نتيجة التعرض المزمن للمعادن الثقيلة المذكورة. 